\title{
Women and the Challenges of the Future of Islamic Education
}

\author{
Fadlil Munawwar Manshur \\ Fakultas Ilmu Budaya, Universitas Gadjah Mada Yogyakarta \\ Email: fadlil@ugm.ac.id \\ N. Hani Herlina \\ Program Pascasarjana, Institut Agama Islam Darussalam (IAID) Ciamis, Indonesia \\ Email: haniherlina@iaid.ac.id

\begin{abstract}
Ahmad Nabil Atoillah
Program Pascasarjana, Institut Agama Islam Darussalam (IAID) Ciamis, Indonesia Email: ahmadnabil@iaid.ac.id
\end{abstract}

Received: June 22, 2020 | Accepted: December 2, 2020

\begin{abstract}
This study seeks to elaborate on the position and function of women in the realm of Islamic education. This study uses the critical review method, a method used to interpret texts critically. The results of the study show that Muslim women in Indonesia are in fact part of Muslim women in other parts of the world. However, Indonesian Muslim women tend to have greater opportunities and chances in facing a bright future of education. Within Islamic education institutions, the viewpoint of women has shifted from a conservative view to a more egalitarian one. The oldest and largest Islamic education institution in Indonesia, namely pondok pesantren, is accustomed in using the terminology of equality and alignment relatives to gender as their educational discourse. They are not only fluent in discussing the concept of gender equality, the terminology has even become part of the practice of pondok pesantren education.
\end{abstract}

\begin{abstract}
Abstrak
Kajian ini berupaya untuk mengelaborasi kedudukan dan fungsi perempuan dalam kancah pendidikan Islam. Kajian ini menggunakan metode critical review, sebuah metode yang digunakan untuk memaknai teks-teks secara kritis. Hasil kajian menunjukkan bahwa kaum perempuan Muslim di Indonesia sejatinya bagian dari kaum perempuan Muslim di belahan dunia lain. Namun demikian, perempuan Muslim Indonesia cenderung memiliki kesempatan dan peluang yang lebih besar dalam menyongsong masa depan pendidikan yang gemilang. Di lingkungan lembaga pendidikan Islam, cara pandang terhadap perempuan sudah bergerser dari pandangan konservatif menuju pandangan yang lebih egaliter. Institusi pendidikan Islam tertua dan terbesar di Indonesia, yaitu pondok pesantren, sudah terbiasa menjadikan terminologi kesetaraan dan kesejajaran gender sebagai wacana pendidikan
\end{abstract}


mereka. Mereka tidak hanya fasih mewacanakan konsep kesetaraan gender, terminologi itu bahkan sudah menjadi bagian dari praktik pendidikan pondok pesantren.

\section{Keywords}

Women, gender, Islamic education

\section{Pendahuluan}

For some women, the reform era in Indonesia eleven years ago gave a lot of promise and provided opportunities to increase their role and selfactualization. For those who are active in the community, such as in nongovernmental organizations (NGOs), socio-political organizations, and other institutions that advocate for women, the reform era has opened a veil and curtain that has been seen as hindering efforts to actualize and the role of women in the public. Not a few of them have taken advantage of the momentum of the reform to increase their involvement in fighting for women's rights. Not a few women's organizations have begun to stretch and show their existence to catch up with men. Women are no longer constrained to convey their aspirations, including through demonstration activities that are disseminated through various television channels and social media. Public discourse in this country is also filled with women's themes, such as gender equality, gender mainstreaming, women's advocacy, the struggle against violence against women, and so on.

Basically, in certain matters, Islam views women as equal to men. Men and women both have the right to enter the heaven promised by Allah. Men and women can compete in goodness (fastabiq al-khairat), worship and serve Allah and do righteous deeds, as God says: "Never will I allow to lost the work of worker among you, whether male and female" (Surah Ali Imran: 195). Although in other respects the roles of men and women are different, basically women are not differentiated from men. Even in the history of Islam, the first person to accept, believe and acknowledge Muhammad as the messenger of God was a woman, namely Khadijah. Khadijah was the first human to prove herself to be a believer and the first Muslim. Aisyah, the Prophet's wife after Khadija's death, was once the commander and leader of men in a war called the Jamal War.

Muhammad Al-Mubarak in his book "Nizdâmu al-Islâm: Al-Hukm wa ad-Daulah" states that a Muslim woman can enjoy her personal rights perfectly. She has the right to own property and spend it, and to run financial business independently when she is an adult and has common sense. She has the right to demand salary equal to those of men if her work is comparable. It is very 
possible that she is a party to a case in court, whether she is the plaintiff or the defendant, even if the other party is her father or husband (Al-Mubarak, 1999).

Muhammad Mubarak further emphasizes that in Islam there are no texts that clearly prohibit women from working in various fields (Al-Mubarak, 1999). However, from a collection of texts and laws relating to women's problems, it can be concluded that the real problem lies in the division of labor between men and women in accordance with their nature and differences in their duties and what has been prepared and provided for them in facing this life, both physically and mentally. On that basis, Mubarak concluded that according to the scriptural texts, the basic task of women is to take care of the family home, starting with efforts to build calm, tranquility, and create an atmosphere of love and care for the education of their children. What Mubarak said emphasizes that Islamic teachings were not discriminatory at all against women. Even if there are differences between men and women, it lies more in the division of tasks and work of each among them.

Within Islamic education institutions, the perspective on women has indeed begun to shift from a conservative viewpoint to a more egalitarian one, even though the change has occurred gradually. The Islamic boarding school (later on mentioned as pondok pesantren) community, for example, is accustomed to using the terminology of equality and alignment relative to gender as a discourse. They are not only fluent in discussing the concept of gender equality, the terminology has even become part of educational practice in pondok pesantren environment.

Women as social beings have advantages and uniqueness. Her strength lies in the multi-role in various areas of life that can be played by women, while her uniqueness lies in her delicate motherhood, tends to be slow and careful, but at the same time, women can also act decisively and courageously in making decisions. The problem is why in the age of advances in science and technology like today there are still a group of people who underestimate women? Furthermore, how can the multi-role of women in various public spaces be recognized and appreciated by the wider community, including women as the main educators, women as life companions, women as pillars of the State, and women as public leaders? This article seeks to elaborate women's issues in the context of the dynamics of Islamic education in the future.

\section{Method}

This study uses critical review method, a method used to interpret texts critically. A number of primary and secondary literatures are read and analyzed 
critically to elaborate the position of women and the challenges of women in education. Most of the primary and secondary literature is the result of research published in various scientific journals. Through this critical review method, the author seeks to investigate women in an educational context more authentically and critically.

\section{Result and Discussion \\ Conception of Women}

Women have the same rights and obligations, in matters of religion, politics, social, culture and education. Therefore, women are not "the second human being" (second class human being). Pre-Islamic Arab society, the position of women was highly disrespected, even having a daughter was a "disgrace", so that it had to be buried alive (Fyzee, 1999, p. 5). In Asaf AA Fyzee's view, "The position of woman at the time of Prophet Muhammad was no better than that of animals: they had no legal rights; in youth they were the goods and chattels of the father and after marriage the husband, became their lord and master". Polygamy was universal, divorce was easy, and female infanticide was common". (Fyzee, 1999, p. 5). Meanwhile, David Pearl confirmed that "women were treated as 'objects of sale'; they were fully exploited by their fathers, and could be sold in marriage to the highest bidder. The husband was entitled to terminate the contract of marriage on any occasion and on any whim (Pearl, 1979, p. 1). In terms of marriage, W. Robertson Smith stated, "Arabs also practiced marriage by capture, marriage by purchase, marriage by inheritance, and mut'ah (temporary) marriage." (Smith, 1903, p.7).

Later, came the teachings of Islam conveyed by the Prophet Muhammad, thereby elevating the status of women to their glory. David Pearl stated that "One of Muhammad's major aims was to alleviate the deprived role of the woman, and thus much of the legal material to be found in the Qur'anic verses concerns the very real attempt to enhance the legal position of the woman (Pearl, 1979, pp. 2-3). Later, John Esposito and DeLong-Bas argue that some of the most and fundamental reforms of customary law introduced in the Qur'an were designed to improve the status of women and strengthen the family in Muslim society (Esposito \& DeLong-Bas, 2001, p. 17 ).

Indonesian history records that women as a wife as well as a mother play an important role. In Ambon, women were at the forefront of the church city council, their intelligence is valued. In Aceh, women were able to fight against the Dutch colonialists (Tjut Nyak Dien). In Minangkabau, women were known for their wisdom in politics (Putri Bundo Kanduang). In Bali, women managed 
agricultural land that was the same size as that of men (Muzakkar \& Aini, 2014, p. 49).

Etymologically, women come from the word "empu" which means "valued". Conceptually, women are interpreted as beings or entities that deserve respect. As for the word "woman", comes from the word "wan" means "lust", therefore, the word "woman" means a creature or something that is used as an object of lust. An expert on Islam, Gustave le Bon emphasized that "Islamic virtuous deeds are not limited to honoring and respecting women, but rather, we can add that Islam is the first religion to honor and respect. We can easily prove this by illustrating that all religions and nations, prior to the advent of Islam, caused much harm and insult to women" (Le Bon, 1974, p.448). Symbolically, the change from the word woman to female changes the meaning from object to subject. In Maulana Vahiduddin Khan's view, "God" created man's mate from the same soul" means simply that women are of the same species as men" (Khan, 1995, p. 227).

\section{Women in the Qur'an}

Quran (Al-Hujurat, 49: 13) does not differentiate faiths according to gender. "O mankind, indeed We have created you from male and female and made you people and tribes that you may know one another. Indeed, the most noble of you in the sight of Allah is the most righteous of you. Allah is Knowing and Acquainted".

Qur'an (Al-Ahqaf, 46: 19) states that men and women are equally responsible for their actions. "And for all there are degrees for what they have done, and so that He may fully compensate them for their deeds, and they will not be wronged".

Quran surah Al-Isra verse 70 considers all human beings worthy of equal respect, "And We have certainly honored the children of Adam and carried them on the land and sea and provided for them of the good things and preferred them over much of what We have created, with definite preference".

Quran surah An-Nisa verse 7 recognizes women's rights to property in general and prohibits improper means of obtaining them. For men there is a share of the inheritance of the mother and father's relatives, and for women there is a share of the inheritance of the mother and father, both a little or a lot according to the predetermined part.

In Surah Al-'An'am verse 151, God upholds the right to life and considers women to be holy. Say, "Come, I will recite what your Lord has prohibited to you, that tou not associate anything with Him, and to parents good 
treatment, and do not kill your children out of poverty; We will provide for you and them. And do not approach immoralities, what is apparent of them and what is concealed. And do not kill the soul which Allah has forbidden (to be killed) except by (legal) right. This has He instructed you that you may use reason".

With regard to this verse, Al-Hibri emphasized that the life of a woman has the same value as the life of a man. Islam makes killing women a crime the same as killing men (Al-Hibri, 1997, p. 74). And Khalid Ishaque states "The modern constitution guarantees a number of different freedoms, while the Qur'an sets out a comprehensive declaration" (Ishaque, 1974, p. 21).

\section{Roles and Challenges of Islamic Women}

In the family environment, Muslim women (mothers) are the main educators for their children. Mother is a true builder of a small community, namely in the family environment, "Mother is like a madrasah (school), if you prepare them well, then you are preparing a nation with good roots." Later, it is also stated that "Mother is like a teacher of all important teachers, Her influence reaches the world (Al-Bantanie, 2006, pp. 83-84). A shalihab Muslim woman, she will be a life companion that is pleasant for her husband; she becomes an entertainer in sadness, a motivator, a reassurer of the soul when he is restless. The roles of women in Islam include:

First, women as the main educators. When Muslim women have carried out their role as primary educators and as good life companions, it means that they have upheld the pillars of the state. If a mother has neglected her role as an educator, there will be births without morality which in turn will destroy the state.

There are several noble and exemplary women who have succeeded in playing their roles as primary educators in the history of Muslims, namely (i) Khadijah Binti Khuwailid, wife of the Prophet Muhammad. She is a successful entrepreneur, smart, tough, and a good life companion, (ii) Aisyah Binti Abu Bakr Ash-Shiddiq, nicknamed "Humaira", is a smart, broad-minded, independent woman and a pleasant life companion (Qutb, 2009: 75), (iii) Asma' Binti Abu Bakr Ash-Siddiq, sister of Aisyah, a noble, intelligent and unyielding female warrior. Asma was nicknamed "Dzatun-Nithaqaini" a woman who had two scarves because she tore it in half. One for the Prophet"s food, and one for covering her face. This incident occurred on the night of the Prophet's hijrah (Salim, 2002, p. 45). 
Second, women as life companions. Thus, the role of women in development does not mean that they have to be active in political, social, business and other activities outside the home. This affirmation does not mean that women should not have activities outside the home. Outside activities are still permissible and even very important, but proportionally women must be able to balance household life with activities outside the home. Education experts almost agree, that the behavior and future of children is largely determined by factors of education at home. This home education factor will encourage children's motivation, trust, discipline, and behavior in achieving achievements in education and skills. Children who will be at stake in the future of this country's development need to be equipped with religious enthusiasm and values, so that various factors and negative impacts of development can be resisted internally by them. In the Islamic perspective, women should not be ashamed to be good housewives. There is also no need to feel humiliated concerning being the guide and educator of children at home. Due to by being a good mother or being a guide and educator for children in the home, women actually have done very noble and valuable actions; and thus according to his true nature.

By becoming mothers, mentors, and educators of children, mothers can teach and educate our children with various knowledge, examples, wisdom and all the provisions needed for the future of our children. The Word of Allah which reads: "Just as We sent among you a Messenger from yourselves reciting to you Our verses and purifying you and teaching you the Book and wisdom, and teaching you what you did not know" (QS Al-Baqarah:151). From the verse above, there are at least 5 (five) kinds of activities that women can do in the house: (1) reciting verses of the Qur'an to children who are unable to read them by themselves; (2) purifying the minds and morals of children through education, love, advice and wise prohibitions; (3) teaching the Book of Allah to children, by reading, translating, understanding and explaining the purposes contained in the Qur'an; (4) teaching wisdom and discretion to children. These are able to be done by providing interesting stories containing wisdom and discretion, from the stories of the Qur'an, the stories of the Prophets, friends, Islamic and world leaders, as well as local stories; and (5) teaching knowledge to children. These are able to be done through efforts to guide children in reading, doing school work, finding interesting and relevant books, accompanying children when watching TV and so on. If the five matters above are done regularly and become a habit at home, it means that mothers have actualized their true nature. 
Third, women as pillars of the state. Women can take part in social, political, state, economic and trade life. And there are already so many examples for this. Siti Khadijah was a famous merchant of her time, Siti Aisyah was respected not only as a well-known hadith narrator, an accomplished critic, but also as an army commander. Zainab bint Jahsy (Prophet's wife) was a worker as an animal skin tanner. Asy-Syifa is known as a writer/secretary trusted by the Caliph Umar ibn al-Khaththab to take care of the market in Medina. Not a few women are also known as scholars and teachers of famous scholars. Asy-Shaykh Syuhrah was called Fakhr an-Nisa (the pride of women) was a teacher of Imam Shafi'i. Also Mu'nisat Al-Ayyubiyah (daughter of Al-Malik Al-Adil, Salahuddin Al-Ayubi's brother), Saimiyat al-Taimiyah, and Zainab (daughter of historian Abdul Latif al-Baghdadi) were teachers of Syafi'i madhhab. Not to mention if it includes contemporary female figures, such as Benazir Butho, Maryam Jameelah, or our Vice President and others (Salim, 2002).

They are women who are not only lucky but also have the same knowledge and skills as men. They have never demanded gender justice and equality, but they prove that the role of women is not inferior to that of men. Justice and gender equality do not need to be prosecuted or challenged. What is necessary is how women prove their role in the field of life, so that automatically the principles of justice and gender equality belong to everyone.

However, no matter how much the principles of equality and "alignment relative" to gender have been owned by women, proportionally women should still play a more optimal role in the family and in the field of children"s education, especially education in the family environment. Raising and educating children in a family environment is not a job that is humiliating, embarrassing and greedy. What is the meaning of an activity outside the home, if the children are psychologically and educatively neglected in their own house. "Whoever does righteousness, whether male and female, while he is a believer, We will surely cause him to live a good life, and We will asurely give them their reward according to the best of what they use to do" (QS An -Nahl: 97). "And their Lord responded to them: "Never will I allow to be lost the work of worker among you, whether male or female" (Surah Ali Imran: 195). "Every one of you is a leader and you shall be asked about those you lead".

Fourth, women as leaders of Islamic boarding schools (pondok pesantren). The development of religious education in Indonesia, with pondok pesantren as the forerunner, has subsequently experienced quite encouraging developments. Currently, pondok pesantren in Indonesia are not only led by men 
but also by women. These schools were initially very simple and consisted only of kyai, santri, mosques and pondok (Dhofier, 1982); over time, according to the demands of the times, they began to adapt to existing developments. Pondok pesantren which were originally dominated by masculine culture, nowadays feminism is also part of the spirit of the pesantren. Initially, pondok pesantren was better known as an educational and religious teaching institution for men, later it expanded its function as a social institution, which also played a role in fostering the surrounding community, including empowering women, without forgetting its main purpose as an educational institution and religious teaching. Even in the pre-independence era and during the physical revolution, pondok pesantren became the center of forging and the headquarters of the fighters.

Towards the 20th century, the development of Islamic education in Indonesia experienced very encouraging progress. This was in line with the change in the religious attitude of the Indonesian people at that time and there were some encouragement that led to changes in the movement of Indonesian Muslims. First, since 1900 in several places there has been a desire to return to the Qur'an and Sunnah, which are used as starting points for evaluating existing religious and cultural customs. The central theme of this trend is rejecting blind taqlid. Second, national resistance against the Dutch colonial rulers, which were nationalist in nature and did not respond to the idea of Pan-Islamism that was raised in the Middle East. Third, there is a strong desire and effort from Muslims to strengthen their organization in the socio-economic field. Fourth, there are efforts to reform Islamic education, in which some Islamic organizations are dissatisfied with the traditional education system (Bruinessen, 1994, pp. 2627). Efforts to reform Islamic education include changing the gender paradigm.

As a result of these motivations, the desire to renew and develop Islamic education has flourished in various places, especially in Sumatra and Java, including involving women in Islamic education. In 1907, in Padang Panjang, madrasah Adabiyah was established by Abdullah Ahmad, a madrasah (religious school) that was more modern in style. In Yogyakarta, at the end of 1923, four Muhammadiyah elementary schools had been established, and had started pioneering the establishment of HIS and teacher education schools (Bruinessen, 1994, pp. 38-39). In other areas, such as in Tebuireng (East Java), Majalengka (West Java), Medan (North Sumatra) and other religious education began to be developed by taking a modern, open, dialogical, and caring style for women"s education.

In general, the development of religious education that occurred at that time underwent changes from an individual or sorogan teaching system to a 
classical system, as well as the provision of material for general knowledge in addition to religious knowledge. It was this change in the pattern of religious education that became the forerunner of the madrasah as they are known today.

Since efforts to modernize Islamic education have been carried out, to date the number of religious education institutions - especially in the form of pondok pesantren and madrasah - has reached thousands and is widespread in urban areas and even in remote villages. In addition to these two types of Islamic education systems, there are also other internal structures of Islamic education in Indonesia, namely Islamic general education, that is Islamic education which is carried out through the development of an Islamic-inspired educational atmosphere in educational institutions that carry out general education programs; as well as Islamic religious lessons held in general educational institutions as a subject or course (Buchori, 1989, p. 184).

With thousands of numbers and widespread in various regions, ideally Islamic education should be able to play a role in various fields of national and state life, namely through its graduates or outputs. But in reality, the expected ideals of Islamic education have not been maximally successful, in accordance with the challenges it faces. Since Islamic education in Indonesia is an inseparable part of the national education system, the development of Islamic education cannot be separated from the development of the national education system as its core. In Law Number 2 Year 1989 concerning the National Education System, it is stated that the purpose of National Education is to educate the nation's life and develop Indonesian people as a whole, namely people who believe and fear God Almighty and have noble character, knowledge and skills, health physically and mentally, a solid and independent personality and a sense of social and national responsibility.

Without reducing the meaning and ideals of these goals, looking at the existing conditions and reality, it seems that it will be very difficult for an educational institution, including Islamic education, to fulfill the objectives of the National Education. However, according to the objective mission and challenges faced by the Indonesian people, inevitably Islamic education must carry a dual mission, namely on the one hand Islamic education must be able to increase the faith and piety of students, and on the other hand it must equip them with knowledge modern knowledge and technology.

With such a mission, the style of Islamic education must be directed at (1) the classical education system, which emphasizes more on efforts to educate the nation in general, including the development of character and morals of alkarimah, and (2) the education system that refers to on manpower planning. In 
other words, if Islamic education wants to produce students who have advantages in the fields of modern science and technology, as well as develop their knowledge and appreciation of the values of Islamic teachings, like it or not, classical education which is based on Islamic boarding school education must be accompanied by madrasah system, which are more accessible to women.

Seeing the pattern of Islamic education that developed in Indonesia, the orientation of education that is directed to develop and enhance knowledge and live the values of Islamic teachings, does not seem to be such an urgent problem. Due to students in the Islamic education environment, both pondok pesantren and school education (from Madrasah Ibtidaiyah to University) are very conducive to achieving this orientation. In fact, the challenge faced seriously is how Islamic education is able to prepare students to compete in the world of work after they graduate. This challenge certainly requires practitioners of Islamic education to reoriented in the field of curriculum, especially regarding the basic materials of modern science and technology.

In fact, the output of Islamic education has not been able to fill the necessity of available employment opportunities. Those who have muqim (out) from pondok pesantren, according to tradition, usually continue the struggle of their teachers by establishing and becoming caregivers of new pondok pesantren. Or at least become a Qur'an teacher, imam at mosque and obtain the title of ustadz, kyai or ulama from the community. Even if there are alumni of pondok pesantren who are involved in the economic world, this is limited to the trade and service sector in a small scope. Due to their limited managerial abilities and skills, their businesses in the economic sector find it difficult to develop, moreover compete with modern economic institutions.

Meanwhile, alumni of formal Islamic education schools, starting from the level of Madrasah Ibtidaiyah (MI) to Islamic Universities on average can only fill job vacancies in the government bureaucracy, particularly the Ministry of Religion. Although there is no doubt that many alumni of Islamic education are involved in politics and economics, they are still in a very limited situation. Therefore, the work orientation of Islamic education graduates from the school or formal route remains in the government bureaucracy. Unfortunately again, due to the recruitment process of Civil Servant Candidates (CPNS) who do not pay attention to one's achievements and professionalism, and pay more attention to the factors of money, relatives and acquaintances; as a result, a mentality gradually develops among students who are more oriented towards prestige than oriented towards achievement and 
expertise. As the result is the desire of students to immediately graduate and hold degrees and diplomas without regard to the quality of their education.

Fifth, Muslim women as scientists. Facing the 3rd millennium era, the mastery and control of the impact of science and technology must be the mind of Islamic education practitioners. Mastery of science and technology for women is absolutely necessary considering the global development of modern society cannot be separated from science and technology. However, efforts to control and prevent the negative impact of science and technology must also be a priority for Islamic education. In Sachiko Murata's perspective, efforts to prevent the negative impact of science and technology on nature will be very effective if you use a feminist perspective (Murata, 1996). The position of Islamic education in an effort to control and prevent the negative impact of science and technology is very significant, given the tendency of the objective reality of modern society to turn and depend on the spirit of religious spirituality.

Anticipating the development of science and technology, it cannot be forgotten that the development of future sciences is informatics, materials technology (biochemistry), biotechnology and microelectronics (Sularto, 1990, p. 118). These four types of knowledge will have a broad impact on future economic and cultural life. How Islamic education and Islamic women can anticipate the four developments in science and technology and other science and technology, is clearly a serious problem. In this context there are at least two problems faced by Islamic education and Islamic women, namely:

First, the problem related to dualism-science. The dualism of science between "religious sciences" on the one hand and "secular sciences" on the other hand was originally born due to of the dualism or separation between the religious education system and the general education system. This dualism in fact does not only occur in Indonesia, but also exists in the education system in almost all Muslim countries.

As a result of the dualism of this science, psychologically it has produced negative images or stereotypes against general or secular sciences among Muslims, including school-age children. Cynical terms, such as kafir science, kafir language and others, we often hear in the mention of general sciences or English. This psychological factor may also lead to a lack of interest in students to follow general materials in the Islamic education environment. For example, when Madrasah Aliyah (MA) still used majors or study programs of Religion, Physics, Biology, Social Sciences and Languages; the interest of students in choosing study programs outside the Religious Sciences (A.1) is not that great 
- if not very little. It is not uncommon for the teachers to seduce and force a little so that they want to choose a study program outside the Religious Sciences.

Second, problems related to the qualifications of teachers and teaching staff. The problem of teacher qualification or teaching staff is not only faced by Islamic education, but is a common problem faced by the national education system (Amiruddin, 1997, p. 138). In the Islamic education environment, in general it is found that there is a mismatch between the abilities and educational background of teachers and the subject matter they hold.

As it is known, the teachers or teaching staff in the Islamic education environment mostly come from the Islamic education environment - especially the PGA and PTAI Tarbiyah Faculty - whose professionalism skills in the field of science and technology are less adequate. In fact, not infrequently, due to the limited number of teachers, basic science and technology materials are held by those who are not experts. In Madrasah Aliyah, for example, many graduates of the Tarbiyah Faculty of Islamic Religious Education (PAI) have held physics, biology, chemistry and other subjects. In addition, Islamic education also faces an imbalance between the supply and demand of teachers or teaching staff, where at one point there is an accumulation of the number and quality of teachers, while in other places it is very deficient.

The external challenges faced by Islamic education and Islamic women today can at least be divided into two types. The first is the challenge that develops simultaneously with the crises experienced by humans and modern civilization, which occurs global. Meanwhile, the second is the challenge faced more specifically by the Indonesian people. As is known, modern civilization, which most people are now passing through, is a civilization built on the paradigm of rationalism, materialism and positivism. The prevailing logic is always based on rationalistic, materialistic and positivistic logic. With this paradigm and logic, modern society has produced a civilization that has led humans to extraordinary progress and has provided various conveniences, pleasures and comforts.

Unfortunately, the modernization, which so fascinates and captivates everyone, has had a very concerning impact. It does not only make humans as individuals lose their integrity (read: their souls); social joints are increasingly destroyed; even overexploitation of nature has brought about an alarming ecological crisis. In such conditions, modern civilization does not hesitate to reduce everything that is beyond its logical reach. Humans only believe in things that can be accepted by reason. Anything that is irrational is seen as superstition. 
As a result, modern society experiences what is called objectivation (Kuntowijoyo, 1991, p. 289) when it is in the midst of industrial machines, political machines and market machines. Science and technology have also contributed to the reductionistic tendency which sees man in a partial and incomplete way, in terms of matter and spirit. The process of objectivation and reductionistic tendencies in looking at human beings ultimately causes alienation of humanity from their so-cultural environment. It is not surprising that more and more modern industrial societies are suffering from stress, even crazy, as a result of the continuous boredom they experience. The lousy and darker people and modern civilization is described by Paul Kleer, as follows:

Western man is very narrow-minded and almost unable to make any contact with the culture and other people he meets. He must see himself in the context of the wider world and reduce his pride. He imagined himself free and called the whole world, 'Free yourselves. Break with tradition. Be like us. Become a modern human being.' This fairy tale must be challenged — that we, as modern humans, could not succeed without the knowledge of our ancestors and could not act in an entirely different way, obeying completely different laws. Now Western humans feel less secure. The unreasonably high expectations placed on science and technology are proven wrong. Western civilization has reached a critical point that is clearly visible from the ecological crisis that affected Western society at the spiritual level, emotional level and level of inner life (Sardar, 1989, pp. 283-284).

In Western countries, in line with the development of modern industry, the development of social diseases has also increased drastically. 'Alija' Ali Izetbegovic, the President of Bosnia Herzegovina, stated that the crime and crime rate in the United States in 1965 was $178 \%$ higher than the population growth of 13\% (Izetbegovic, 1992, p. 86). This is not to mention the increase in alcoholism, pornography, drug addiction and gambling, which are eating away at their social joints.

Seeing the increasingly alarming development of modern society, many of the figures in various parts of the world are increasingly aware of the importance of the presence of religion in the midst of society. Symptoms and the tendency of the community to re-interpret religion are increasingly visible. In fact, John Naisbitt and Patricia Aburdene, two US futurologists, predicted a revival of religion in the third millennium (Naisbitt \& Aburdene, 1990, p. 254). In the context of the awakening of society to these religions, Islamic education is challenged to be proactive, not only in extracting the values of Islamic 
teachings, transferring and internalizing them to students; but also challenged to make itself as a center of excellence in conducting Islamic and social studies.

The next challenge is the challenge of Indonesian-ness. Due to its global nature, the crisis that hit modern society was also experienced by some Indonesians. However, in addition to the challenges faced by modern society globally, Indonesian society - especially women, is also faced with more specific challenges. Since Situbondo, Tasikmalaya, Ujungpandang cases that occurred in the last decade of the New Order era; as well as cases of Ketapang, Kupang, Ambon, Palu, and others that occurred since the reform era; Indonesian people witnessed how the people were very vulnerable to riots, looting, arson and even murder. Indeed, these cases are not only characteristic of Indonesian society. People in other countries also face similar cases, such as in Pakistan, India, Ireland, and even the United States itself, which is the master of democracy, is not free from riots that relating to ethnicity, religion, race and inter-group relations.

However, due to the frequency which these cases have happened to the Indonesian people, it isnormal that people call these cases specific and characteristic of the social life of our society lately. surely, the incidents that befell the Indonesian nation were caused by complex factors. Why do people become so violent, rude, irritable and provocative, intolerant? The answers can be many. It might be due to hunger, jealousy, feeling oppressed, feeling unfairly treated, or it could be due to there is something that is not right in religious knowledge and appreciation. We are of the opinion that one of the factors causing the various riots in the country is due to the perhaps inaccurate knowledge and appreciation of the Indonesian people, which in turn develops an attitude of intolerance.

This fact clearly brings consequences and becomes a special challenge for religious education in Indonesia. At least we can ask questions: Has the delivery of religious materials in general, and the values of Islamic teachings in particular, been carried out incorrectly? Or has religious education so far provided students with something that makes them intolerant? Later, how to prepare a religious education learning model that is conducive to the creation of a safe, peaceful and tolerant life atmosphere? The questions above inevitably must be answered immediately. And if the answer is "Yes", then as soon as possible an alternative solution must be found. If not, then the Indonesian nation, particularly the women, will always be faced with a "time bomb" which can at any time explode and destroy the social order that has been fostered. 


\section{Conclusion}

Muslim women in Indonesia are actually part of Muslim women in other parts of the world. However, Indonesian Muslim women tend to have greater opportunities and chances in facing a bright future of education. Within Islamic education institutions, the viewpoint of women has shifted from a conservative view to a more egalitarian one. The oldest and largest Islamic education institution in Indonesia, namely pondok pesantren, is accustomed in using the terminology of gender equality and parallel as their educational discourse. They are not only fluent in discussing the concept of gender equality, the terminology has even become part of pondok pesantren education practice.

\section{REFERENCE}

Al-Bantanie, M. S. (2006). Bidadari Dunia; Potret Ideal Wanita Muslim. Jakarta: Qultum Media.

Al-Hibri, A. (1997). A Study of Islamic Herstory: or How did We Ever Get into this Mess. In A. Al-Hibri (Ed.), Women and Islam. Oxford: Pergamon Press Ltd.

Al-Mubarak, M. (1999). Nizdâmu al-Islâm: Al-Hukm wa ad-Daulah. Cairo: Maktab al-Tsaqafah al-Islâmiyah.

Amiruddin, A. (1997). Sekolah Sebagai Transformator Wawasan Keunggulan Bangsa. In M. D. Rahardjo (Ed.), Keluar dari Kemelut Pendidikan Nasional: Menjawab Tantangan Sumber Daya Manusia Abad 21. Jakarta: Intermasa.

Bruinessen, M. van. (1994). Pesantren, Madrasah, Sekolah: Pendidikan Islam Dalam Kurun Modern. Jakarta: LP3ES.

Buchori, M. (1989). Pendidikan Islam di Indonesia: Problema Masa Kini dan Perspektif Masa Depan. In M. Azhari \& A. M. Saleh (Eds.), Islam Indonesia Menatap Masa Depan. Jakarta: P3M.

Dhofier, Z. (1982). Tradisi Pesantren: Studi Tentang Pandangan Hidup Kyai. Jakarta: LP3ES.

Esposito, J., \& DeLong-Bas, J. (2001). Women in Muslim Family Law. Syracuse: Syracuse University Press.

Fyzee, A. A. A. (1999). Outline of Muhammadan Law. Oxford: Oxford University Press (OUP).

Ishaque, K. (1974). Human Rights in Islamic Law'. Review of the International 
Commission of Jurists, 12, 30-39.

Izetbegovic, 'Alija 'Ali. (1992). Membangun Jalan Tengah: Islam antara Timur dan Barat. Bandung: Mizan.

Khan, M. W. (1995). Woman Between Islam and Western Society. New Delhi: The Islamic Centre.

Kuntowijoyo. (1991). Paradigma Islam: Interpretasi Untuk Aksi. Bandung: Mizan.

Le Bon, G. (1974). La Civilisation des Arabes. Oxford: Oxford University Press. Murata, S. (1996). The Tao of Islam. Bandung: Mizan.

Muzakkar, M., \& Aini, D. I. (2014). Perempuan Pembelajar. Jakarta: Elex Media Komputindo.

Naisbitt, J., \& Aburdene, P. (1990). Sepuluh Arah Baru untuk Tabun 1990-an: Megatrends 2000. Jakarta: Binarupa Aksara.

Pearl, P. (1979). A Textbook on Muslim Law. London: Croom Helm.

Salim, M. I. (2002). Perempuan-Perempuan Mulia di Sekitar Rasulullah saw. Jakarta: Gema Insani Press.

Sardar, Z. (1989). Rekayasa Masa Depan Peradaban Muslim. Bandung: Mizan.

Smith, W. R. (1903). Kinship \& Marriage in Early Arabia. London: Adam and Charles Black.

Sularto, S. (1990). Menuju Masyarakat Baru Indonesia: Antisipasi Terhadap Tantangan Abad XXI. Jakarta: Gramedia Pustaka Utama. 
